\title{
The Role of Store Atmosphere on Purchase Decision: Case of Cafes in Banda Aceh
}

\author{
Teuku Roli ILHAMSYAH PUTRA', \\ Cut APRILIA, ${ }^{2}$ \\ Ade $A U L I A^{3}$
}

\begin{abstract}
The purpose of this study is to test the effect of store atmosphere variables on purchasing decisions. This study is conducted by using quantitative approach. The population is 37 cafe in Banda Aceh. Cluster sampling is used in this study, so the number of samples is determined as many as 100 respondents. This research also obtains some data from journals and books as the secondary data. Simple linear regression analysis was used to analyze the data. The result shows that store atmosphere variables have a positive and significant effect on purchasing decision of consumers. It means that store atmosphere has an important role to influence consumers decision. It is proved by regression coefficients store atmosphere from the results of the t test which is amount to 6.973 greater than t table which is equal to 1.984. In conclusion, the store atmosphere thatbuild a comfortable situation for the consumers, can increase the purchase decision of them.
\end{abstract}

KEYWORDS: Store Atmosphere, Purchasing Decision

JEL CLASSIFICATION: D70, D80, D81.

\section{INTRODUCTION}

The retail industry is currently in great demand by the community because of its dynamic nature. One of the retail industries that is currently developing is restaurant and cafe. Retail business owners, especially stores, must be able to anticipate changes that continue to occur in the current global era quickly and responsibly in adapting to these changes. The way to anticipate these changes is to make new innovations in businesses that are being managed or innovated in new businesses. These innovations should be adapted to the development of the lifestyle of today's society. The lifestyles of the people who began to adopt the behavior of hedonism made them compete to find everything that could fulfill their satisfaction. One of them is visiting a café and restaurant that now not only offers food and drinks but also offers design and comfort atmosphere. Nowadays, food tastes and service quality are no longer the main reasons consumers choose dining places, now the atmosphere is the most important factor for consumers in choosing aplace to eat. The atmosphere of a cafe with unique and

\footnotetext{
${ }^{1}$ Universitas Syiah Kuala, Indonesia, Email: teuku.roli@unsyiah.ac.id

${ }^{2}$ Universitas Syiah Kuala, Indonesia

${ }^{3}$ Universitas Syiah Kuala, Indonesia
} 
creative decorations is the main attraction that makes consumers decide to visit a cafe. Berman and Evans (2013) stated that the image of firms depends on the firm atmosphere. Store atmosphere contributes greatly to images projected to consumers. Atmosphere is understood through the customer's psychological feelings when visiting a store. Similarly, atmosphere refers to the design of the environment through visual communication, lighting, color, music, and smell to stimulate the customer's perceptual and emotional responses and ultimately influence buying behavior. It also can affect people's enjoyment in shopping and spending time at the cafe. Aceh is one of Indonesia provinces that experience a significant growth in the number of cafes in the city. The competition is getting tougher especially in Banda Aceh as the provincial capital. In order to compete in the business, the café need to have its own characteristcis that will differ it from the other cafes. Since most cafes have subtle differences in the product offered, creating a distinctive atmosphere can be considered as an alternative to differentiate one café to another. Kotler (1973) suggested to use the atmosphere of a service setting as the discrimination element to differ one service settings to another. Hence, the purpose of this study is to find out whether the store atmosphere has a partial or simultaneous effect on the purchase of consumer cafes in the city of Banda Aceh.

\section{LITERATURE REVIEW}

\section{Store Atmosphere}

Store atmosphere is an environmental design such as visual communication, lighting, color, music, and aroma to simulate customer perceptual and emotional responses and ultimately affect their buying behavior. Berman and Evans (2013) developed four dimensions of store atmosphere, namely: 1) Exterior (Cafe Outside), 2) General Interior (General Interior), 3) Store Layout (Layout Cafe), 4) Interior (Point of Purchase) Displays.Exterior has strong influence in the image formulation of a café/store. It consists of storefront, marquee, store entrances, exterior building height, surrounding storesand the surrounding area, parking facilitiesas well as display windows. According to Berman and Evans (2013) general interior is the dimension that can influence customers' perception. The dimension consists of flooring, lighting and colors, scent and sounds, store fixtures, wall textures, temperature, aisle create and technology. Store layout includes allocation of the floor space for merchandise and the customer, classification of store offering, determination of a traffic-flow pattern, determination of space nedds, mapping out in-store locations and arrangement of individual products. Another dimension in store atmosphere is point of purchase (POP) display. This dimension provides information for the customer, influence café atmosphere and has a role as promotion tool. It includes assortment display, a theme setting display, ensemble display, a rack and case display as well as a cut case and dump bin.

\section{Purchase Decision}

According to Kotler and Keller (2013) and (Kemal et al., 2015) the purchasing decision process consists of five stages carried out by a consumer before arriving at a purchase decision and then after a purchase. Consumers' purchase-decisions can occur if the consumer has received service from the provision of services. Subsequently, consumers feel the existence of 
satisfaction and dissatisfaction. Therefore, the concepts of purchase decisions can not be separated from the concept of customer satisfaction. According to Kotler and Lane (cited in Hidayat, 2012), the indicators of purchasing decision are 1) Introduction to Problems, 2) Information Search, 3) Alternative Evaluation, 4) Lighting (lighting), 5) Post-purchase behavior.

Previous study showed that store atmosphere has significant effect on consumer purchase decision (Putri et al., 2014; Jasniko 2013).

Following is the testing of the research hypothesis:

H1: How do atmospheric stores and consumer purchases affect the café.

The theoretical framework in this study will explain the relationship between each variable and can be seen in Figure 1:

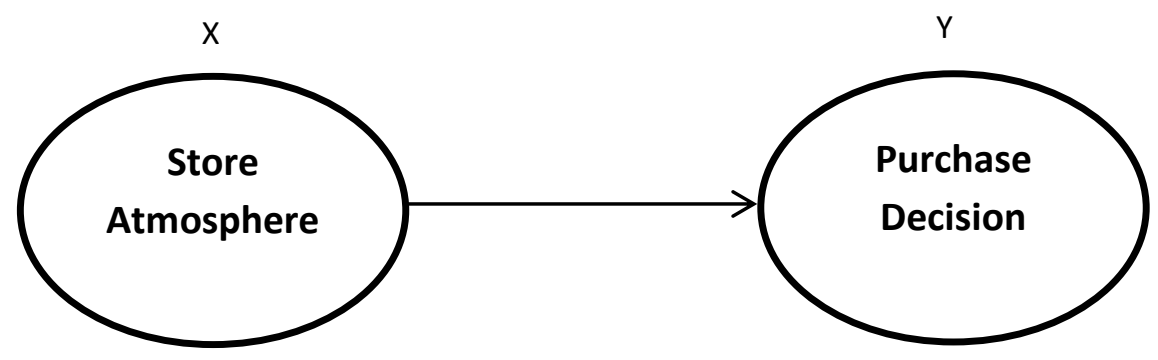

Figure 1.Research Paradigm

\section{METHOD}

The population in this study is visitors to the cafe in Banda Aceh, with 37 cafes in Banda Aceh. The sample was determined by cluster sampling ddue to the large number of cafes in Banda Aceh. Sampling techniquestwo stages were used, which is the first stage to determine the sample area, and the second stage to determinethe number ofrespondents in the selected area randomly. Finally, 100 respondents were chosen from various café in Banda Aceh area.

To obtain data and information for this study, questionnaire was used and wasdistributed privately to the respondents while they were in the cafe. It consits of 50 statements and used Likert Scale with range of scale from 1(strongly disagree) to 5 (strongly agree). Subsequently, the data was analysed using Regression analysis with the help of SPSS Software version 22. The data was subjected to validity and reliability test before tested the hypothesis.

Below is the question list (questionnaire) that needs to be answered by respondents.

A. Respondent Identity

Name

Age 
Sex

Marital Status :

Last Education :

B. Question That Related to Variable

\begin{tabular}{|c|c|c|c|c|c|c|}
\hline \multirow{2}{*}{ NO } & \multirow{2}{*}{ Question } & \multicolumn{5}{|c|}{ Answer } \\
\hline & & 1 & 2 & 3 & 4 & 5 \\
\hline \multicolumn{7}{|c|}{ ATMOSFER STORE } \\
\hline \multicolumn{2}{|c|}{ Exterior } & & & & & \\
\hline 1 & Signboard clearly visible & & & & & \\
\hline 2 & Nameplate has an attractive design & & & & & \\
\hline 3 & Display a unique cafe building & & & & & \\
\hline 4 & Cafe logo in the city of Banda Aceh is clearly visible. & & & & & \\
\hline 5 & Display the unique cafe entrance & & & & & \\
\hline 6 & $\begin{array}{l}\text { The entrance of the cafe is convenient for entering and leaving the } \\
\text { cafe }\end{array}$ & & & & & \\
\hline 7 & Display window cafe makes me interested in entering into it & & & & & \\
\hline 8 & Spacious vehicle parking location & & & & & \\
\hline 9 & Vehicle safety when parking is guaranteed & & & & & \\
\hline 10 & Vehicle safety when parking is well guarded & & & & & \\
\hline 11 & Cafe parking location does not cover the front view of the cafe. & & & & & \\
\hline 12 & The location of the cafe is very strategic and easy to reach & & & & & \\
\hline 13 & The layout of tables and chairs outside the cafe is neatly arranged & & & & & \\
\hline \multicolumn{7}{|c|}{ GeneralInterior } \\
\hline 14 & The cafe area is very spacious and comfortable & & & & & \\
\hline 15 & The cafe floor is different from other cafes & & & & & \\
\hline 16 & Cafe room lighting makes me comfortable & & & & & \\
\hline 17 & The music inside the cafe makes me comfortable & & & & & \\
\hline 18 & The aesthetics of arranging equipment in the cafe are very good & & & & & \\
\hline 19 & The air in the cafe room feels cool & & & & & \\
\hline 20 & The library provided is neatly arranged & & & & & \\
\hline 21 & Cafe employees serve customers well & & & & & \\
\hline 22 & Cafe employees have good product knowledge offered to consumers & & & & & \\
\hline 23 & Equipment in the cafe looks classic and traditional & & & & & \\
\hline 24 & Cleanliness of the interior of the cafe is neatly maintained & & & & & \\
\hline 25 & Facilities (sink and wc) look clean & & & & & \\
\hline 26 & The color of the walls in the cafe looks bright and attractive & & & & & \\
\hline 27 & Aroma of a fragrant cafe room & & & & & \\
\hline 28 & Food and drinks delivered to consumers according to my order & & & & & \\
\hline \multicolumn{7}{|c|}{ Store Layout } \\
\hline 29 & $\begin{array}{l}\text { Access to the Mushalla (place for prayer) at the cafe is } \\
\text { easy }\end{array}$ & & & & & \\
\hline 30 & Mushalla (place for prayer) placement is right in its place & & & & & \\
\hline 31 & Access to the toilet in the cafe is easy & & & & & \\
\hline 32 & Placement of toilet and sink right in place & & & & & \\
\hline 33 & $\begin{array}{l}\text { The seats available at the cafe can accommodate } \\
\text { customers who come }\end{array}$ & & & & & \\
\hline 34 & Chairs and tables available are comfortable to occupy & & & & & \\
\hline
\end{tabular}




\begin{tabular}{|c|c|c|c|c|c|c|}
\hline \multirow{2}{*}{ NO } & \multirow{2}{*}{ Question } & \multicolumn{5}{|c|}{ Answer } \\
\hline & & 1 & 2 & 3 & 4 & 5 \\
\hline 35 & The distance between the table and chairs is wide & & & & & \\
\hline 36 & $\begin{array}{l}\text { The distance between tables and chairs with one another } \\
\text { makes it easy for consumers to pass by }\end{array}$ & & & & & \\
\hline 37 & Food and beverage menu arrangement looks interesting & & & & & \\
\hline 38 & Food and beverage menu arrangement looks neat & & & & & \\
\hline 39 & Payment table placement is right & & & & & \\
\hline 40 & $\begin{array}{l}\text { The payment table placement makes it easy for } \\
\text { transactions }\end{array}$ & & & & & \\
\hline \multicolumn{7}{|c|}{ Interior (Point Of Purchase)Displays } \\
\hline 41 & Layout design makes me want to spend the night at the cafe & & & & & \\
\hline 42 & Pictures and posters in the cafe look interesting & & & & & \\
\hline 43 & The pictures and posters in the cafe match the theme & & & & & \\
\hline 44 & Signs cashier, toilet and westhafel clearly visible & & & & & \\
\hline 45 & Employees' clothes according to the theme of the cafe & & & & & \\
\hline \multicolumn{7}{|c|}{ Consumer Purchase Decision } \\
\hline \multicolumn{7}{|c|}{ Problem Recognition } \\
\hline 46 & I need a cafe that can make a good mood. & & & & & \\
\hline \multicolumn{7}{|c|}{ Information Search } \\
\hline 47 & I always look for information about cafes from various media & & & & & \\
\hline \multicolumn{7}{|c|}{ Alternative Evaluation } \\
\hline 48 & I always compare the facilities of every cafe I visit & & & & & \\
\hline \multicolumn{7}{|c|}{ Buying decision } \\
\hline 49 & $\begin{array}{l}\text { I decided to visit this Cafe because I felt comfortable and } \\
\text { the food and drinks provided at this cafe were according } \\
\text { to my tastes and desires. }\end{array}$ & & & & & \\
\hline \multicolumn{7}{|c|}{ Post Purchase Behavior } \\
\hline 50 & I feel satisfied with the facilities provided by this Cafe. & & & & & \\
\hline
\end{tabular}

\section{RESULT}

\section{Characteristic of Respondents}

According to age group, respondents were dominated by 21-26years old at 38 percent. The proportion shows that the majority cafe consumers are youth. While based on the gender, the number of respondents who are male is more dominant than the female, 62 percent and 38 percent, respectively. The number of respondents who were not married was 86 percent while the respondents who were married were not as many as 14 percent. The number of high school graduates is 11 percent, diplomas are 30 percent and S1 are 39 percent, while S2 is 14 percent and $\mathrm{S} 3$ is 6 percent. 


\section{Validityand Reliability Test}

The validity test in the study shows that there are all instruments having a calculated $r$ value greater than $r$ table and a significance value of less than 0.05 . So that all instruments from the store atmosphere variables are declared valid and feasible to be tested further. Test reliability of statement items from a questionnaire using the value of Cronbach Alpha that amount 0.91 that shows the research instruments all have coefficient values greater than the significant cronbach alpha level values $>0.90$. So that all can be declared reliable and can be further tested.

\section{Regression}

Simple regression analysis is a model to determine the effect of independent variables such as store atmosphere on the dependent variable, namely consumer purchasE decisions. In this study using a computer program that is SPSS version 20 for Windows. A summary of the results of data processing using the SPSS program presented in Figure is as follows:

Table 2. Regression Result

\begin{tabular}{|c|c|c|c|c|c|}
\hline Variabel & $\begin{array}{l}\text { Unstd. } \\
\text { Coeff. }\end{array}$ & $\begin{array}{c}\text { Std. } \\
\text { Error }\end{array}$ & Std. Coeff. & $\mathbf{t}$ & Sig \\
\hline $\begin{array}{l}\text { Constant } \\
\text { Store atmosphere }\end{array}$ & $\begin{array}{l}3.279 \\
0.094\end{array}$ & $\begin{array}{l}2.564 \\
0.013\end{array}$ & 0.576 & \begin{tabular}{|l|}
1.279 \\
6.973
\end{tabular} & $\begin{array}{l}0.204 \\
0.000\end{array}$ \\
\hline $\begin{array}{l}\text { Dependent Variabel:Purchase D } \\
\text { Standard Error of the estimate } \\
\mathrm{R} \\
\mathrm{R}^{2} 0.332 \\
\text { Adjusted } \mathrm{R}^{2} 0.325\end{array}$ & & & & & \\
\hline
\end{tabular}

The result shows the store atmosphere variable has a positive and significant influence on purchase decision of the consumers. This means that store atmosphere has an important role in influencing consumer purchasing decisions. This is proven by store atmosphere regression coefficients from the results of the t test amounting to 6.973 greater than t table is equal to 1.984. This means that store atmosphere can create pleasant comfort for consumers, so the more, both store atmosphere, the better the consumer's perception of the store atmosphere and the greater the consumer's encouragement to make purchases at the cafe. Store Atmosphere is an important factor to be able to make consumers feel interested in coming to visit and comfortable to buy. Such cafe settings, of course, can attract visitors' attention and give a positive and negative impression of a shopping center. According to Berman \& Evans (2013) Store Amosphere can be meant that a store is important to highlight physical appearance, store atmosphere is useful to build image and attract customer interest. Atmosphere relates to how managers can manipulate building design, interior space, hallway layout, carpet and wall textures, smells, colors, shapes and sounds that consumers experience that all aim to influence consumers in their buying decisions. Store Atmosphere is also related to designing an 
environment through visual communication, lighting, color, music and smell to stimulate perceptions and emotions from customers and ultimately influence consumers to make purchasing decisions.

\section{CONCLUSION AND DISCUSSION}

Overall store atmosphere has a positive and significant influence on consumer purchasing decisions. It means the café atmosphere in Banda Aceh is comfortable and pleasing to the consumer. In other words, the better the store atmosphere, the better consumer perception and the bigger encouragement for the consumer to visit the café. However, on the general interior indicators, the respondent gave low rating on the cleanliness of the sink and toilet in the cafe. It means for the customer, the cleanliness of café in Banda Aceh has not reached to customer expectation. While, the design layout of the café and the security of the parking space receive the highest average point showing that this become the reason customers are willing to spend more time in the café.

\section{IMPLICATIONS}

The finding of this study can be used to support the management strategy in developing store atmosphere to increase sales. For example, the café owner shoud care more on the cleanliness of the sink and toilet since this element can create negative perception about the café. For a businessperson who wants to start café business, s/he should focus more on design of the café layout since it is one of the reasons of why customers are willing to spend more time at the café. When the customers spend their time more at the café, they eventually will order more food. As a result, the café will be profitable. The café owner also should provide security in the parking space, because it will determine the customers experience spending their time in the café. If they worry about the security of their car, they will tend to be unpleasant being in the café. As a result, they will spend less time in the café.

\section{REFERENCE}

Berman, B., \& Evans, R. J. (2013). Retail Management, a Strategic Approach, (8th Edition). New Jersey: Pearson.

Hidayat, A. M., Wibowo, S., \& Hidayat, R. (2012). Studi Komperatif Faktor - Faktor Consumer Oriented Promotion yang Mempengaruhi Keputusan Pembelian Di Supermaket Studi Kasus (Matahari Dept. Store \& Toserba Yogya) Bandung 2012. Consumer Oriented Promotion, 9-10.

Jasniko, W. (2013). Pengaruh Atmosfer Toko Dan Variasi Produk Terhadap Keputusan Pembelian Konsumen Pada Swalayan Citra Bandar. Padang.

Kemal,Y., Kubulay, C., \& Mehmet L. H. (2015). The effect of age, gender and education level on customer evaluations of retail furniture store atmospheric attributes. Journal of Retail \& Distribution Management, Vol.43(8), 712-726. 
Kotler, P. (1973). Kotler - Atmospherics as a marketing tool (cité 171) - 1973. Journal of Retailing, 14-64.

Kotler, P. \& Kelvin L. (2013). Marketing Management. Global Edition. Pearson Prentice Hall. Levy, M. \&Weitz, B. (2012). Retailing Management. McGrawHill, Irwin, New York.

Putri, L.H., Putri S.H. \& Kusumawati, A. (2014). Pengaruh Store Atmosphere Terhadap Keputusan Pembelian Dan Kepuasanelanggan (Studi pada Monopoli Cafe and Resto Soekarno Hatta Malang). Jurnal Administrasi Bisnis, 15 (2). 